\section{New in paper}

\section{Surrealism}

The Road to the Absolute Anna Balakian

$\$ 12.50282$ pages (est.) 25 halftones

\section{Love Known}

Theology and Experience in George Herbert's Poetry Richard Strier

$\$ 12.95 \quad 300$ pages

\section{Romantic Re-Vision}

Culture and Consciousness in Nineteenth-Century

American Painting and Literature Bryan Jay Wolf

$\$ 15.95292$ pages 63 halftones

\section{Victorian and} Modern Poetics Carol T. Christ

$\$ 7.95 \quad 188$ pages

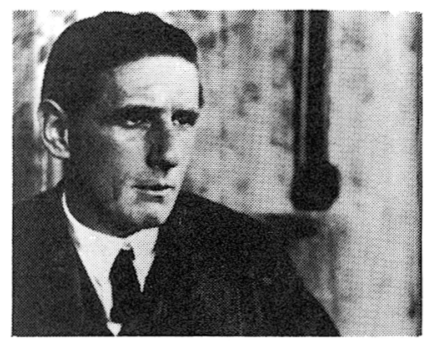

Hermann Broch Ernestine Schlant $\$ 9.95194$ pages (est.)

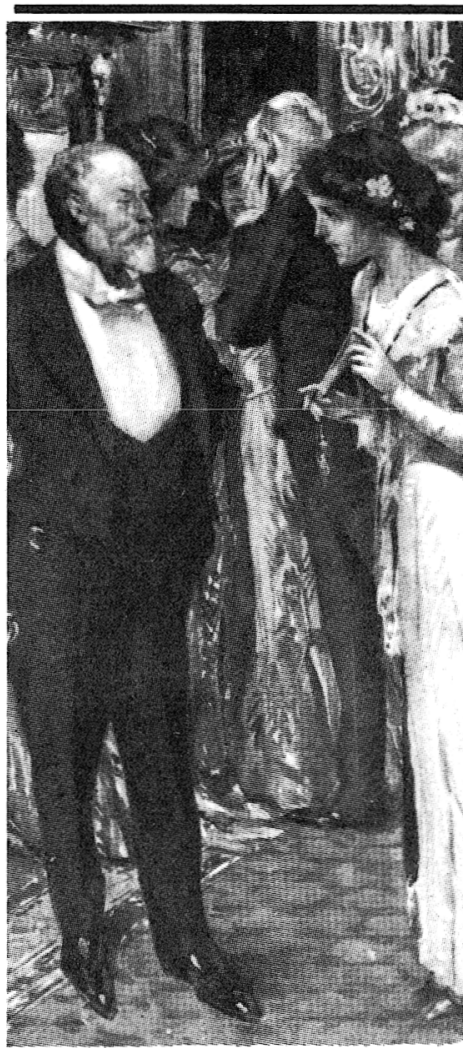

\section{Cossip}

Patricia Meyer Spacks

$\$ 10.95308$ pages (est.)

\section{Etymologies}

and Genealogies

A Literary Anthropology

of the French Middle Ages

R. Howard Bloch

$\$ 11.95294$ pages

The Language of Criticism and the structure of Poetry Ronald S. Crane

$\$ 15.00 \quad 234$ pages

A Midway Reprint
Fiction and poetry

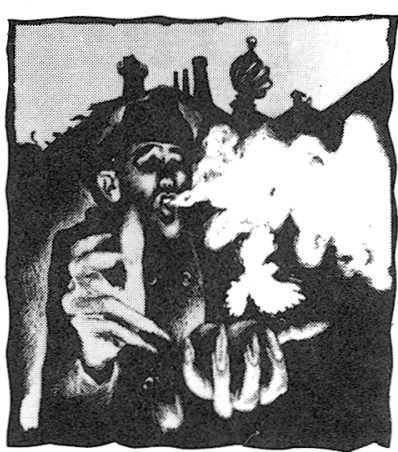

The Dragon

Fifteen Stories

Yevgeny Zamyatin

Translated and Edited by Mirra Ginsburg

$\$ 9.95 \quad 302$ pages

Call the Next Witness

Philip Mason

$\$ 5.95 \quad 220$ pages

Through Streets

Broad and Narrow

Gabriel Fielding

$\$ 9.95 \quad 346$ pages

Phoenix Fiction

\section{Hurricane Lamp}

Turner Cassity

Paper $\$ 6.95 \quad 75$ pages

Library cloth edition $\$ 15.00$

Phoenix Poets

\section{Hapoy Hour}

\section{Alan Shapiro}

Paper $\$ 7.95$ (est.) 64 pages

Library cloth edition $\$ 20.00$ (est.)

Phoenix Poets many other titles at the CHICAGO display
20\% MEETING DISCOUNT 


\section{New Paperbacks from Cornell}

WRITING AND MADNESS

Literature/Philosophy/

Psychoanalysis

By SHOSHANA FELMAN. Translated from the French by Martha Noel Evans and the author with the assistance of Brian Massumi. \$9.95

\section{GYNESIS}

Configurations of Woman

and Modernity

By ALICE JARDINE.

$\$ 12.95$

THE COSMIC WEB Scientific Field Models and Literary Strategies in the Twentieth Century BY N. KATHERINE HAYLES. $\$ 8.95$ MODERN DRAMA AND GERMAN CLASSICISM Renaissance from Lessing to Brecht

By BENJAMIN BENNETT. $\$ 12.95$ ROMAN COMEDY

By DAVID KONSTAN.

\section{OPERA}

The Extravagant Art

By HERBERT LINDENBERGER.
OPERA AND IDEAS From Mozart to Strauss By PAUL ROBINSON.

$\$ 9.95$

\section{DICKINSON}

The Anxiety of Gender

By VIVIAN R. POLLAK.

$\$ 8.95$

"MADAME BOVARY" ON TRIAL

By DOMINICK LaCAPRA. \$8.95

\section{DARK}

INTERPRETER

The Discourse of Romanticism

By TILOTTAMA RAJAN. \$8.95

\section{SYMBOLISM AND INTERPRETATION \\ By TZVETAN TODOROV. Trans-} lated by Catherine Porter. $\$ 7.95$

\section{RUSSIAN} FORMALISM

\section{A Metapoetics}

BY PETER STEINER,

LITERATURE AS RECREATION

IN THE LATER MIDDLE AGES

By GLENDING OLSON.

Additional new books inside. See these and other books of interest at Booth \#93-94. 